\title{
Nodulation and Yield of Pigeonpea Based Intercropping System as Influenced by Integrated Nutrient Management in Mollisols of the Tarai Region
}

\author{
Singh Ashutosh ${ }^{1 *}$, Pandey Amit Kumar ${ }^{1}$, V.K. Singh ${ }^{2}$ and Singh Umesh ${ }^{1}$ \\ ${ }^{1}$ Department of Soil Science and Agricultural Chemistry, Bihar Agricultural University, \\ Sabour-813210, Bhagalpur (Bihar), India \\ ${ }^{2}$ Department of Agronomy, College of Agriculture, G.B. Pant University of Agriculture \& \\ Technology, Pantnagar- 263145 (Uttarakhand), India \\ *Corresponding author
}

\begin{tabular}{l} 
Ke y w o r d s \\
Intercropping system, \\
$\begin{array}{l}\text { PSB, FYM, } \\
\text { Nodulation, Pigeonpea } \\
\text { equivalent yield }\end{array}$ \\
\hline Article Info \\
\hline $\begin{array}{l}\text { Accepted: } \\
\text { 20 July } 2018 \\
\text { Available Online: } \\
\text { 10 August } 2018\end{array}$ \\
\hline
\end{tabular}

A B S T R A C T
The effect of integrated nutrient management on nodulation and yield of pigeonpea based intercropping system were investigated. A field experiment was carried out during kharif season of 2007 and 2008 at N.E. Borlaug Crop Research Centre, Govind Ballabh Pant University of Agriculture and Technology, Pantnagar, Uttarakhand to assess the effect of three cropping system (pigeonpea sole, pigeonpea + blackgram and pigeonpea + maize), two levels of inoculation [with and without phosphorus solubilizing bacteria (PSB)] and three levels of farm yard manure $\left(0,2.5\right.$ and $\left.5.0 \mathrm{t} \mathrm{ha}^{-1}\right)$ on nodulation and yield of pigeonpea, blackgram and maize. Eighteen treatment combinations were replicated three times in a factorial randomized block design. The soil of experimental site is characterized as upland Mollisols of the Tarai region. Results revealed that intercropping of blackgram with pigeonpea recorded higher values of nodules characters of pigeonpea such as number of nodules per plant, nodule fresh weight, nodule dry weight, nodulation index and yields of pigeonpea and its equivalent over its other counter parts. Similar results were also obtained with PSB-inoculation and FYM @ $5.0 \mathrm{t} \mathrm{ha}^{-1}$ for nodulation and yield of main \& inter crop.

\section{Introduction}

Pulses have played an important role in the agricultural economy in sustaining the productivity of soil. Out of major rainfed pulses, pigeonpea [Cajanus cajan (L.) mill sp.] is one of the most important pulse crop grown in India. The low productivity of pigeonpea in the country may be ascribed to many reasons, however inadequate and imbalanced fertilization, limited seed inoculation, indeterminate growth, flower drop and dry matter partition are important. It has potential to give comparable yield under improved management system. Pigeonpea have been replaced by short duration and photo-insensitive cultivars, viz. 'UPAS 120', 'T21', 'ICPL 87'. The cultivation of these varieties becomes popular because they provide opportunity for late sown wheat 
(Triticum aestivum L. emend.).There is possibility of growing short duration intercrops like blackgram (Vigna mungo L.), greengram and cow pea with pigeonpea, as the growth of the letter crop plants remain quite slow with little canopy during early stage (Rajput et al., 1995).The green revoulation brought impressive gains in food production but due to intensive use of agro-chemicals soil biodiversity is being disturbed. There is now fabulous pressure on growers to use integrated nutrient management approach to increase productivity and soil health. Organic amendment offers an alternative tactic to increase production (Meena, 2013). Biofertilizers are cheaper, eco-friendly and based on renewable energy sources has gained momentum to supplement the parts of chemical fertilizer (Meena et al., 2015a). Inoculation with an effective and persistent PSB strains has numerous benefits, which increase the pod yield due to increased nodulation (Podile, 1995). The use of farmderived source such as FYM has extensively been used in various crops. These organic additives can be used to promote the development of beneficial organisms in the soil, water holding capacity and cation exchange capacity (Singh et al., 2008). Organic amendment also increases the efficiency of biofertilizers. Therefore, the present investigation was undertaken to see the response of 'UPAS 120' a short duration pigeonpea cultivar, to study the effect of integrated nutrient management on nodulation and yields of component crops in pigeonpea based intercropping system in Mollisols of Tarai region.

\section{Materials and Methods}

Achallenge was made to study the response of pigeonpea based intercropping system to integrated nutrient management on Mollisols. A field experiment was conducted during kharif seasons of 2007 and 2008 at N.E.
Borlaug Crop Research Centre, GovindBallabh Pant University of Agriculture and Technology, Pantnagar is situated at $29^{\circ} \mathrm{N}$ latitude, $79^{\circ} 30^{\prime} \mathrm{E}$ longitude and at an altitude of 243.83 meter above mean sea level (M.S.L.) under sub-humid and sub-tropical climate zone with hot dry summers and cool winters in Tarai region, $25 \mathrm{~km}$ away from the foot hills of Himalayas. Tarai region remains dry from early October to mid-June and wet from mid-June to early October. The maximum temperature is recorded in MayJune $\left(38^{\circ} \mathrm{C}\right)$ and the lowest in DecemberJanuary $\left(4^{\circ} \mathrm{C}\right)$ with occasional frost. Relative humidity is the highest in July $(81 \%)$ and the lowest in May (37\%). The average annual rainfall is $1400 \mathrm{~mm}$ and most of it is received during monsoon season between June and September. The soil of experimental area was sandy loam in texture with neutral $\mathrm{pH}$ (7.2). Eighteen treatments comprised of three cropping system (pigeonpea sole, pigeonpea + blackgram and pigeonpea + maize), two levels of inoculation (with PSB and without PSB) and three FYM levels $\left(0,2.5\right.$ and $\left.5 \mathrm{t} \mathrm{ha}^{-1}\right)$ were tested in factorial randomized block design with three replications. The crop pigeonpea (cv. UPAS-120), blackgram ( $c v$. Pant Urd-40) and maize ( $c v$. Surya) was sown on $2^{\text {nd }}$ and $16^{\text {th }}$ July during 2007 and 2008, respectively. The plant-to-plant spacing of pigeonpea and maize was maintained at $20 \mathrm{~cm}$ and of blackgram at $10 \mathrm{~cm}$ by thinning out extra plants at 15 days after sowing. Intercultural operations i.e. weeding and bird watching were taken care of during crop growing season in both the years. After field preparation, a basal dose of $20 \mathrm{~kg} \mathrm{~N}, 40 \mathrm{~kg} \mathrm{P}_{2} \mathrm{O}_{5}$ and $30 \mathrm{~kg}$ $\mathrm{K}_{2} \mathrm{O} \mathrm{ha}{ }^{-1}$ to pigeonpea \& blackgram and $60 \mathrm{~kg}$ $\mathrm{N}, 60 \mathrm{~kg} \mathrm{P}_{2} \mathrm{O}_{5}$ and $40 \mathrm{~kg} \mathrm{~K}_{2} \mathrm{O} \mathrm{ha}^{-1}$ to maize was applied irrespective of fertilizer treatment. Remaining half amount (60 kg N ha ${ }^{-1}$ ) was top-dressed to maize rows only in two equal splits at knee height and tasseling stages. The $\mathrm{N}, \mathrm{P}$ and $\mathrm{K}$ were applied through urea, single super phosphate and muriate of potash. Seeds 
of crops were inoculated with PSB (Bacillus polymyxa) before sowing. The crop was sprayed with thiodon + metasystox (1:1 ratio) by using 700 litres of water $\mathrm{ha}^{-1}$ at $90 \mathrm{DAS}$ and pod filling stages for the control of Maruca and Heliothis. Intercrop blackgram was harvested at 100 and 105 days after sowing (DAS) while maize was harvested at 94 and 83 DAS during 2007 and 2008, respectively. The pigeonpea crop was harvested on $29^{\text {th }}$ December in 2007 and $30^{\text {th }}$ December in 2008. The experimental site experienced a total rainfall of 1244.8 and $1667.2 \mathrm{~mm}$ during the crop period in 2007 and 2008 , respectively.

Five plants were randomly selected in each plot to count the number of nodules per plant and weighed to get their fresh weight. The nodules thus obtained was kept in the petri dish and dried in the oven at $70 \pm 1{ }^{\circ} \mathrm{C}$ for 48 hours to record the dry weight of nodules per plant. The nodulation index, which accounts for the effect of the plant size on nodules mass, was calculated for each plant sample by using the formula as suggested by Betts and Herridge (1987).

Nodule dry weight per plant (g) Nodulation index $=$ X 100

Dry matter yield per plant $(\mathrm{g})$

The plants from the net plot area (9.6 square meters) in each plot were harvested, bundled, weighed after sun drying.

Thereafter, the materials were threshed and to record the biological yield (grain + stalk yield) per plot, which was converted to $\mathrm{kg} \mathrm{ha}^{-1}$. The pigeonpea equivalent yield was calculated by using following formula:

Pigeonpea equivalent yield $\left(\mathrm{q} \mathrm{ha}^{-1}\right)=[$ Price of urd/maize x Yield of urd/maize $\left.\left(\mathrm{q} \mathrm{ha}^{-1}\right)\right]$ / [Price of pigeonpea] + Yield of pigeonpea (q $\mathrm{ha}^{-1}$ )
All the data were analyzed statistically by applying ANOVA technique (Panse and Sukhatme, 1978). The differences among treatments were compared by applying " $F$ " test of significance at 5 per cent of probability.

\section{Results and Discussion}

\section{Effect of integrated nutrient management in pigeonpea based intercrop on nodulation}

The data pertaining to number of nodules per plant, fresh weight, dry weight and nodulation index of pigeonpea are furnished in table 1 . The number of nodules, fresh and dry weight of nodules per plant and nodulation index in pigeonpea significantly increased under pigeonpea + blackgram intercropping system compared to sole and pigeonpea + maize intercropping. Higher values of no. of nodules (11.68 and 11.2), nodule fresh weight (169.0 and $154.67 \mathrm{mg} \mathrm{plant}^{-1}$ ), nodule dry weight (17.85 and $15.66 \mathrm{mg} \mathrm{plant}^{-1}$ ) and nodulation index (0.2053 and 0.2056) in pulse + pulse intercropping system during both the years. Better nodulation and more fresh and dry weight occurred in pigeonpea + blackgram intercrop of pigeonpea that might be attributed to better photosynthesis and translocation of photosynthate to root nodules, because of adequate light and space. These results are in secure accord with the findings of Singh and Faroda (1986).

The enhancement in nodulation in terms of nodule, their fresh and dry weight and nodulation index per plant of pigeonpea were obtained by the efficiency of inoculated of Bacillus polymyxa in the results in both the years over uninoculated control. PSBinoculation resulted in significant increase in nodule number, their fresh and dry weight and nodulation index of pigeonpea $(9.08,119.56$ $\mathrm{mg}, 13.92 \mathrm{mg}$ and 0.1763 in 2007 and 8.57 , $111.22 \mathrm{mg}, 12.21 \mathrm{mg} \& 0.1808$ in 2008), respectively. 
Table.1 Nodules number, fresh weight, dry weight and nodulation index of pigeonpea as influenced by integrated nutrient management in pigeonpea based intercropping system

\begin{tabular}{|c|c|c|c|c|c|c|c|c|}
\hline \multirow[t]{2}{*}{ Treatment } & \multicolumn{2}{|c|}{$\begin{array}{l}\text { No. of Nodules per } \\
\text { plant }\end{array}$} & \multicolumn{2}{|c|}{$\begin{array}{l}\text { Nodule Fresh Weight } \\
\left(\mathrm{mg} \mathrm{plant}^{-1}\right)\end{array}$} & \multicolumn{2}{|c|}{$\begin{array}{l}\text { Nodule Dry Weight } \\
\left(\mathrm{mg} \mathrm{plant}^{-1}\right)\end{array}$} & \multicolumn{2}{|c|}{ Nodulation Index } \\
\hline & 2007 & 2008 & 2007 & 2008 & 2007 & 2008 & 2007 & 2008 \\
\hline \multicolumn{9}{|l|}{ A. Cropping System } \\
\hline Sole pigeonpea & 9.32 & 8.78 & 110.00 & 101.83 & 14.06 & 12.33 & 0.1831 & 0.1867 \\
\hline Pigeonpea + Blackgram & 11.68 & 11.02 & 169.00 & 154.67 & 17.85 & 15.66 & 0.2053 & 0.2056 \\
\hline Pigeonpea + Maize & 3.99 & 3.80 & 39.33 & 37.00 & 6.34 & 5.56 & 0.1128 & 0.1157 \\
\hline S.Em. \pm & 0.18 & 0.17 & 2.37 & 2.01 & 0.22 & 0.19 & 0.0018 & 0.0017 \\
\hline CD (5\%) & 0.51 & 0.48 & 6.82 & 5.78 & 0.62 & 0.54 & 0.0053 & 0.0050 \\
\hline \multicolumn{9}{|l|}{ B. PSB inoculation } \\
\hline With PSB & 9.08 & 8.57 & 119.56 & 111.22 & 13.92 & 12.21 & 0.1763 & 0.1808 \\
\hline Without PSB & 7.58 & 7.17 & 92.67 & 84.44 & 11.58 & 10.16 & 0.1578 & 0.1579 \\
\hline S.Em. \pm & 0.15 & 0.14 & 1.94 & 1.64 & 0.18 & 0.15 & 0.0015 & 0.0014 \\
\hline CD (5\%) & 0.42 & 0.39 & 5.57 & 4.72 & 0.50 & 0.44 & 0.0043 & 0.0042 \\
\hline \multicolumn{9}{|l|}{ C. FYM levels $\left(\mathrm{tha}^{-1}\right)$} \\
\hline 0 & 6.36 & 6.00 & 62.33 & 58.33 & 9.69 & 8.50 & 0.1449 & 0.1530 \\
\hline 2.5 & 8.09 & 7.63 & 105.17 & 95.33 & 12.31 & 10.79 & 0.1626 & 0.1653 \\
\hline 5.0 & 10.55 & 9.97 & 150.83 & 139.83 & 16.26 & 14.26 & 0.1937 & 0.1897 \\
\hline S.Em. \pm & 0.18 & 0.17 & 2.37 & 2.01 & 0.22 & 0.19 & 0.0018 & 0.0017 \\
\hline CD (5\%) & 0.51 & 0.48 & 6.82 & 5.78 & 0.62 & 0.54 & 0.0053 & 0.0050 \\
\hline $\mathrm{CV}(\%)$ & 9.08 & 9.01 & 9.49 & 8.72 & 7.15 & 7.06 & 4.69 & 4.44 \\
\hline
\end{tabular}


Table.2 Grain yield of component crops and pigeonpea equivalent yield as influenced by integrated nutrient management in pigeonpea based intercropping system

\begin{tabular}{|c|c|c|c|c|c|c|c|c|}
\hline \multirow[t]{3}{*}{ Treatment } & \multicolumn{8}{|c|}{ Yield $\left(\mathrm{Kg} \mathrm{ha}^{-1}\right)$} \\
\hline & \multicolumn{2}{|c|}{ Pigeonpea } & \multicolumn{2}{|c|}{ Blackgram } & \multicolumn{2}{|c|}{ Maize } & \multicolumn{2}{|c|}{ Pigeonpea Equivalent } \\
\hline & 2007 & 2008 & 2007 & 2008 & 2007 & 2008 & 2007 & 2008 \\
\hline \multicolumn{9}{|l|}{ A. Cropping System } \\
\hline Sole pigeonpea & 1631 & 1394 & - & - & - & - & 1631 & 1294 \\
\hline Pigeonpea + Blackgram & 1833 & 1484 & 597 & 486 & - & - & 2476 & 2096 \\
\hline Pigeonpea + Maize & 1057 & 820 & - & - & 2557 & 2047 & 2036 & 1679 \\
\hline 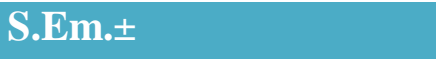 & 57 & 48 & - & - & - & - & 67 & 57 \\
\hline CD $(5 \%)$ & 163 & 137 & - & - & - & - & 193 & 164 \\
\hline \multicolumn{9}{|l|}{ B. PSB inoculation } \\
\hline With PSB & 1581 & 1260 & 641 & 526 & 2760 & 2217 & 2164 & 1791 \\
\hline Without PSB & 1432 & 1139 & 553 & 446 & 2353 & 1876 & 1931 & 1589 \\
\hline S.Em. \pm & 46 & 39 & 24 & 23 & 120 & 94 & 55 & 47 \\
\hline CD (5\%) & 133 & 112 & 77 & 71 & 379 & 296 & 158 & 134 \\
\hline \multicolumn{9}{|l|}{ C. FYM levels $\left(\mathrm{t} \mathrm{ha}^{-1}\right)$} \\
\hline 0 & 1290 & 999 & 463 & 362 & 2054 & 1666 & 1718 & 1384 \\
\hline 2.5 & 1492 & 1189 & 558 & 457 & 2645 & 2049 & 2030 & 1668 \\
\hline 5.0 & 1738 & 1410 & 771 & 640 & 2972 & 2424 & 2395 & 2018 \\
\hline S.Em. \pm & 57 & 48 & 30 & 28 & 148 & 115 & 67 & 57 \\
\hline $\mathrm{CD}(5 \%)$ & 163 & 137 & 94 & 87 & 465 & 362 & 193 & 164 \\
\hline $\mathrm{CV}(\%)$ & 16.01 & 16.82 & 12.26 & 13.98 & 14.13 & 13.74 & 13.91 & 14.34 \\
\hline
\end{tabular}


Podile (1995) also found increasing nodulation in pigeonpea (18-24\%) by the inoculation of seeds with Bacillus subtilis over control. This may be due to produce many plant growthpromoting substance like IAA, gibberellic acids and vitamins etc., which help in the synthesis of nodular tissue.

Application of FYM brought about significant changes in no. of nodules, fresh \& dry weight and nodulation index during both the years. The increased fresh and dry weight of nodules under higher doses of FYM might be because of beneficial effects of FYM on number of nodules assuming that FYM has direct role in biological nitrogen fixation in legumes, by increasing the nodules weight of pigeonpea and intercrop blackgram. Sufficient amount of FYM also enhanced the activities of Rhizobia and increased the formation of nodules. Singh et al., 1998 and Singh et al., 2008 also reported similar findings.

\section{Effect of Integrated Nutrient Management in} pigeonpea based intercrop on yields of component crops and pigeonpea equivalent

Data in respect of grain and straw yield of pigeonpea and intercrop (blackgram and maize) are presented in table 2. Significantly higher grain yield (1833 and $1484 \mathrm{~kg} \mathrm{ha}{ }^{-1}$ ) of pigeonpea was obtained under pigeonpea + blackgram cropping system during both the years as compare to its sole crop (1631 and $\left.1294 \mathrm{~kg} \mathrm{ha}^{-1}\right)$ and intercrop with maize (1057 and $820 \mathrm{~kg} \mathrm{ha}^{-1}$ ). This might be due to complimentary effect of blackgram, which supplemented nitrogen to pigeonpea, and the better utilization of environmental resources in the intercropping system. On the contrary, maize intercropped with pigeonpea had adverse effect on pigeonpea yield resulting in significant reduction in grain yield (54 and 58\%) as comparable to the sole pigeonpea. This might be due to poor dry matter accumulation of pigeonpea crop and vigorous growth of component cereal like maize (Singh and Pal, 2003). Seed inoculation with phosphorus solubilizing biofertilizer recorded significantly improvement in grain yield of pigeonpea (1581 and $1260 \mathrm{~kg} \mathrm{ha}^{-1}$ ) and intercrops viz., blackgram (641 and $526 \mathrm{~kg} \mathrm{ha}^{-1}$ ) and maize (2760 and $2217 \mathrm{~kg} \mathrm{ha}^{-1}$ ) as compared to uninoculation in 2007 and 2008, respectively. This may be due to ability of PSB in producing indole acetic acid, solubilization of tricalcium phosphate, inhibition of Aspergillus flavus and Aspergillus niger in vitro and best in rhizosphere colonizer, which enhanced yield attributing characters of crops and finally the grain yields. These results are in close conformity with those of Reddy et al., 2000.

Grain yield of pigeonpea (1738 and $1410 \mathrm{~kg}$ $\mathrm{ha}^{-1}$ ) and intercrop blackgram (771 and $640 \mathrm{~kg}$ $\left.\mathrm{ha}^{-1}\right) /$ maize (2972 and $2424 \mathrm{~kg} \mathrm{ha}^{-1}$ ) was significantly higher when $5.0 \mathrm{t} \mathrm{FYM} \mathrm{ha}^{-1}$ was applied to crops in 2007 and 2008, respectively. However, application of only chemical fertilizer (no FYM) caused significant reduction in grain yield of crops during both the years. Since FYM forms different organic complexes with the metal cations, it helps in decreasing their losses from the system. This could have helped in manipulation of nodulation and yields.

Erikson and Mortensen (1999) also reported similar findings. The maximum productivity in terms of pigeonpea grain equivalent yield was recorded with pigeonpea + blackgram (2476 and $2096 \mathrm{~kg} \mathrm{ha}^{-1}$ ) which was significantly superior to pigeonpea + maize $(2036+1679 \mathrm{~kg}$ $\mathrm{ha}^{-1}$ ) and sole pigeonpea (1631 and $1294 \mathrm{~kg} \mathrm{ha}$ ${ }^{1}$ ) in both the years. The higher grain equivalent yield under intercropping system might be attributed to additional advantage of intercrop yield and their support rice (Reddy et al., 2007). Similarly, PSB-inoculation and application also increase the pigeon equivalent yield.

\section{Acknowledgement}

We thanks to the Director of the N. E. Borlaug Experiment Station, G.B. Pant University of Agriculture \& Technology, Pantnagar-263 145 for providing financial assistance and Dr. V. K. Singh, University Professor for his valuable comments, suggestions and publication. 


\section{References}

Betts, G. S. and Herridge, N. J. 1987. Impaired nodule function in Medicago polymorpha (L.) infected with alfalfa mosaic virus. Physiologist 117: 243-250.

Erikson, J. and Mortensen, J. V. 1999.Soil sulphur status following long-term annual application of animal manure and mineral fertilizers. Biology and Fertility of Soils 28: 416-421.

Meena, R. S. 2013. Response to different nutrient sources on green gram (Vigna radiata L.) productivity. Indian Journal of Ecology 40: 353-355.

Meena, R. S., Dhakal, Y., Bohra, J. S., Singh, S. P., Singh, M. K. and Sanodiya, P. 2015a. Influence of bioinorganic combinations on yield, quality and economics of mungbean. American Journal of Experimental Agriculture 8: 159-166.

Panse, V. G. and Sukhatme, P. V. 1978.Statistical Methods for Agricultural Workers, $3^{\text {rd }}$ ed., ICAR Publication, New Delhi. 347 p.

Podile, A. R. 1995. Seed bacterization with Bacillus subtilis AF1 enhances seedling emergence, growth and nodulation of pigeonpea. Indian Journal of Microbiology 35: 199-204.

Rajput, O. P., Kumar, Aditya and Sharma, Rakesh Kumar 1995. Intercropping of pigeonpea (Cajanus cajan) with greengram (Phaseolus radiatus) under varying levels of fertility and plant population and its residual effect on succeeding wheat (Triticum aestivum). Indian Journal of Agronomy 40: 563-566.
Reddy, B., Prabhakar and Swamy, S. Narayana 2000. Effect of farmyard manure, PSB and phosphorus on yield and economic of blackgram (Phaseolus mungo). Indian Journal of Agricultural Sciences 70: 694696.

Reddy, M. Malla, Padmaja, B., Malathi, S. and Rao, L. Jalapathi 2007. Productivity of pigeonpea (Cajanus cajan) - based intercropping systems as influenced by fertility and pest management practices under rainfed conditions. Indian Journal of Agricultural Sciences 77: 205-207.

Singh, Adesh, Singh, V. K., Rana, N. S., Kumar, Sanjay, Panwar, G. S. and Kumar, Yogesh 2008. Response of urdbean to farmyard manure and phosphorus application under urdbeanwheat cropping sequence. Journal of Food Legumes 21: 119-121.

Singh, R. C. and Faroda, A. S. 1986.Effect of cropping systems and phosphorus on nodulation in pigeonpea and soil fertility. Indian Journal of Agronomy 31: 203-204.

Singh, S. P., Singh S. P. and Misra, P. K. 1998. Response of short-duration pigeonpea (Cajanus cajan) to nitrogen, Rhizobium inoculation and phosphorus. Indian Journal of Agronomy 43: 681-684.

Singh, T. and Pal, M. 2003. Growth parameter, yield attributes and yields of pigeonpea as influenced by cropping system and nitrogen + phosphorus level. Annals Agricultural Research and News Series 24: 755-759.

\section{How to cite this article:}

Singh Ashutosh, Pandey Amit Kumar, V.K. Singh and Singh Umesh. 2018. Nodulation and Yield of Pigeonpea Based Intercropping System as Influenced by Integrated Nutrient Management in Mollisols of the Tarai Region. Int.J.Curr.Microbiol.App.Sci. 7(08): 3874-3880. doi: https://doi.org/10.20546/ijcmas.2018.708.398 